\title{
Pengembangan Empati Mahasiswa \\ Calon Guru Madrasah Ibtidaiyah
}

Murdianto

Dosen Universitas Islam Sunan Giri (UNSURI) Ponorogo

\begin{abstract}
Numerous acts of violence, war, suffering, loneliness, racism and other social diseases show the world that loss of empathy. Under these conditions a great empathy needed to help with the situation that is happening. Not least in schools, the various phenomena of violence and action that caused loss of empathy also have occurred. Fostering empathy for a teacher is an important task performed by MI's teachers candidates education board to respond the phenomenon. Bibliotherapi techniques can be developed in learning and other settings in developing empathy teachers candidates.
\end{abstract}

Key words: Biblioterapi and empathy, learning, teacher.

\section{Pendahuluan}

Komnas Anak (2010) memandang akar munculnya berbagai kekerasan dalam kehidupan sekolah dapat dilihat dari power relation yang timpang. Salah satunya adalah relasi anak dengan guru. Relasi anak dan guru, salah satunya terwujud dalam interaksi dan komunikasi yang terjadi antara guru terhadap muridnya. Sebagaimana telah dipahami bersama (common sense) pada masyarakat Indonesia bahwa relasi guru murid adalah relasi yang timpang, yaitu relasi antar orang dewasa yang tahu segalanya dengan murid yang dipandang 'tak tahu apa-apa'. Secara keseluruhan relasi model ini berpotensi mengakibatkan tindakan yang tidak sehat dalam interaksi dan komunikasi guru teerhadap murid, dalam bentuk kekerasan, tindakan membentak, menghukum secara berlebihan, menyetrap/mengancam anak didik dan sebagainya.

Data Komisi Perlindungan Anak Indonesia (KPAI) dari tahun 20052009 menunjukkan bahwa kekerasan terhadap anak masih didominasi dalam relasi guru dengan murid. Advokasi Pusat Data dan Informasi 
KPAI pada tahun 2005 (laporan akhir KPAI, 2005) menyebutkan bahwa : $4.9 \%$ kekerasan fisik dilakukan oleh guru laki-laki dan $42.16 \%$ oleh guru perempuan dari total angka kekerasan yang dilakukan orang-orang di sekitar anak. Kekerasan psikis dilakukan oleh $4.1 \%$ bapak guru dan $6.2 \%$ oleh ibu guru dari total angka kekerasan yang dilakukan orangorang di sekitar anak. Sementara kekerasan seksual yang dilakukan bapak guru mencapai $31,7 \%$ dari seluruh laporan yang masuk dari total angka kekerasan yang dilakukan orang-orang di sekitar anak.

Berdasarkan data ini menunjukkan bahwa kekerasan baik fisik maupun psikis didominasi oleh guru perempuan, sementara kekerasan seksual di lakukan guru laki-laki. Berdasarkan data tersebut dapat dilihat kemungkinan faktor gender memainkan peran dalam kekerasan guru kepada murid atau kemungkinan pada level SD dan SMP guru perempuan berjumlah lebih banyak dari jumlah guru laku-laki. Namun data diatas menunjukkan bahwa kekerasan guru terhadap murid yang terdata di KPAI pada tahun 2005, masih cukup memprihatinkan.

Data tahun 2008 masih menunjukkan kecenderungan secara kuantitatif, kekerasan guru terhadap murid masih cukup memprihatinkan. Data Hotline service KPAI 11,3 persen dilakukan oleh guru, mendapatkan rangking kedua setelah kekerasan yang dilakukan orang lain. Padahal dari $88,9 \%$ kekerasan yang lain masih dibagi menjadi beberapa aktor seperti orang tua, saudara, aparat pemerintah, orang lain. Ini membuktikan secara kuantitatifkekerasan yang dilakukan guru terhadap murid masih signifikan. Fakta ini didukung analisis KPAI data pemberitaan kekerasan terhadap anak oleh semua surat kabar. Sepanjang paruh pertama 2008, kekerasan guru terhadap anak mengalami peningkatan tajam yakni 39,6 persen (dari 95 kasus kekerasan terhadap anak) atau paling tinggi dibandingkan pelakupelaku kekerasan pada anak lainnya (http://www.kpai.go.id/publikasimainmenu-33/artikel/34-sekolah-bukan-tempat-aman-bagi-anak-.pdf).

Banyak alasan yang diungkapkan guru dalam menghukum murdinya. Beberapa liputan media massa ini layak direnungkan. Seorang guru (Rus 55 tahun) di Jenu Tuban Jawa Timur, mencabuli puluhan siswa dengan alasan menghukum siswanya karena tidak melaksanakan tugas (Okezone/ Selasa, 10 November 2009). Sementara Dua kepala sekolah yang juga berprofesi sebagai guru, menyiksa Suhel (10) murid Madrasah Ibtidaiyah 
yang mencium anak TK di suatu Madrasah Ibtidaiyah di Sumenep Madura. Mereka beralasan untuk untuk menghukum Suhel agar tidak melakukan perbuatan yang dipandang tidak senonoh tersebut (Kompas Online/Sabtu, 18 April 2009).

Kasus kekerasan serupa yang tidak terpublikasi jauh lebih banyak. Peneliti sendiri menjadi saksi, bahwa suatu sekolah inklusi di suatu Kecamatan di Ponorogo bahwa fihak sekolah dan bahkan jajarana birokrasi diatasnya (UPTD) menutupi kasus ini sebelum muncul di publik yang lebih luas, dengan berbagai alasan, salah satunya nama baik sekolah. Banyak murid yang mengakui bahwa dalam aktivitas belajar-mengajar di sekolah mereka sering mendapat "bentakan, ancaman dan hukuman yang keras" dari guru mereka (www.detik.com tanggal 2 Desember 2006).

Hal ini menunjukkan bahwa cara guru berinteraksi dengan murid diwarnai relasi yang tidak setara, yang cenderung menjadikan murid sebagai obyek 'tindakan tidak empatik', seperti pada tindakan mengancam siswa (menyetrap/mengancam, membentak, menghukum secara fisik dan mental). Sekarang, persoalannya pertama, bagaimana konsep empati yang seharusnya dimiliki oleh seorang guru dan harus diinternalisasi bagi pribadi calon guru, kedua, bagaimana rancangan pelaksanaan pembelajaran yang dilakukan pendidik/guru dengan penggunaan tekhnik biblioterapi yang dapat menumbuhkan empati pada mahasiswa calon guru?

\section{Unsur-Unsur Empati dalam Proses Belajar Mengajar}

Takwin (2008) menulis bahwa unsur -unsur empati dasar yang harus dimiliki oleh seseorang, pertama, imajinasi yang tergantung kepada kemampuan membayangkan. Imajinasi berfungsi untuk memungkinkan pengandaian diri seseorang sebagai orang lain. Kedua, adanya kesadaran terhadap diri sendiri (self-awareness atau self-consciousness). Secara khusus, pandangan positif terhadap diri sendiri dan secara umum penerimaan (dalam arti pengenalan) apa adanya terhadap kelebihan dan kekurangan diri sendiri. Ketiga, adanya kesadaran terhadap orang lain. Pengenalan dan perhatian terhadap orang lain. Secara khusus, pandangan positif terhadap orang lain dan secara umum penerimaan apa adanya terhadap kelebihan dan kekurangan orang lain. Keempat, adanya perasaan, hasrat, ide-ide, dan representasi atau hasil tindakan baik pada orang yang 


\section{Sri Purnami}

berempati maupun pada orang lain sebagai pihak yang diberi empati disertai keterbukaan untuk saling memahami satu sama lain. Kelima, Ketersediaan sebuah kerangka pikir estetis.

Kemampuan empati yang harus dimiliki guru adalah fundamental emphaty, profound emphaty dan functional emphaty (Cooper, 2004). Fundamental emphaty menunjukkan, pertama pemahaman dan sikap yang menerima dan terbuka (being accepting and open), memberi perhatian (giving attention), mendengar (listening), mementingkan (being interested), bersikap positif, dan pendekatan afirmatif (taking a positive and affirmative approach), memperlihatkan antusiasme (showing enthusiasm). Kedua, kemampuan mempertukarkan makna-makna komunikasi melalui ekspresi muka dalam interaksi (facial expression and interaction), corak bahasa tubuh dan gerak (gestures, body language and movement), ketinggian dan jarak (height, and distance), serta bahasa dan tinggi rendah suara (language and tone of voice ).

Sementara, profound emphaty menunjukkan keluasan empati seorang guru dalam aktivitas pembelajaran. Mengembangkan emosi dan interaksi yang positif dalam bentuk interaksi yang menyenangkan, membahagiakan, santai, penuh humor, menyayangi, mencintai, menunjukkan kebaikan, menutupi emosi-emosi negatif (mask negative emotions), pemberi waktu (time-givers), memusatkan perhatian, kontak fisik (physical contact), rileks (relaxed), cepat bersikap, dan iklim yang informal (informal climate) Terakhir, functional emphaty (empati fungsional) adalah fungsi langsung dalam proses belajar mengajar, yakni pertama empati kelompok dan keseluruhan hubungan kelas (group empathy and whole class relationships). Kedua, membangun perspektif terhadap orang lain dalam suatu kelompok (encouraging the perspective of the other in groups) dengan bersama-sama menata pespektif dengan cara memakai setting, pola, serta kode yang melingkar (boundary setting, rules, codes), melakukan kontrol, kedisiplinan, kejujuran tata krama dan struktur yang empatik. Ketiga, pengelompokan mental (mental groupings) yang didasarkan pada kemampuan menggabungkan berbagai tipologi anak, perbedaan kultur, mengejar kelompok yang penuh keberbedaan , dan keberbedaan gender dalam satu situasi mental yang saling berempati, peduli, dan saling menghargai. 


\section{Biblioterapi dan Penggunaan Bahan Bacaan untuk Pembelajaran}

Penggunaan bahan bacaan dalam proses pendidikan atau untuk kepentingan lainmisalnya penyembuhan sudah sangat lama telah digunakan. Gagasan ini sesungguhnya bukanlah gagasan yang baru, karena banyak negara dalam terminologi yang berbeda telah menggunakannya dalam waktu yang lama. Prinsip dasar proses ini ini adalah proses pembelajaran dengan menggunakan media utama buku sebagai bahan bacaan subyek pembelajaran atau subyek yang diterapi. Buku digunakan untuk tujuan penyembuhan. Tujuan yang lebih dari sekedar tujuan menambahkan informasi dan pengetahuan. Yakni, suatu model penggunaan bahan bacaan yang digunakan untuk melakukan perubahan pemahaman dan penyembuhan.

Jachna (2005:1) dalam Bibliotherapy: What, Why and How menulis:

The definition of bibliotherapy is " $A$ form of supportive psychotherapy in which carefully selected reading materials are used to assist a subject in solving personal problems or for other therapeutic purposes". As dry as that definition sounds, that is what bibliotherapy really is. The purpose of bibliotherapy on the other hand is much more intriguing: "to assist a youngster in overcoming the emotional turmoil related to a real-life problem by having him or her read literature on that topic". With the definition and purpose in mind, let us explore where the art of bibliotherapy came from and who is responsible for its creation

Biblioterapi adalah salah satu tekhnik terapi yang memiliki sejarah yang cukup panjang dalam sejarah dunia terapi. Gagasan ini sesungguhnya bukanlah gagasan yang baru, karena dibanyak negara, dalam terminologi yang berbeda menggunakannya dalam waktu yang lama (Olsen, 2007). Biblioterapi berasal dari kata biblion dan therapeia. Biblion berarti buku atau bahan bacaan, sementara therapeia artinya penyembuhaan (Harvey, 2010). Jadi, biblioterapi dapat dimaknai sebagai upaya penyembuhan lewat buku. Bahan bacaan berfungsi untuk mengalihkan orientasi dan memberikan pandangan-pandangan yang positif, sehingga menggugah kesadaran penderita untuk bangkit menata hidupnya.

Prinsip dasar terapi ini adalah proses penyembuhan dengan menggunakan media utama buku sebagai bahan bacaan subyek yang diterapi. 


\section{Sri Purnami}

Biblioterapi adalah "dukungan psikoterapi melalui bahan bacaan untuk membantu seseorang yang mengalami permasalahan personal atau untuk tujuan-tujuan terapeutik yang lain" (Harvey, 2010). Namun Marrs (1995:843) dalam studinya memperluas pengertian biblioterapi sebagai, “ penggunaan bahan-bahan tertulis atau program komputer, mendengar suara /melihat gambar untuk tujuan memperoleh pemahaman atau pemecahan masalah yang relevan pada perkembangan diri seseorang atau untuk tujuan terapitiuk". Proses Biblioterapi dapat dipraktikan oleh seorang fasilitator atau pemberi bantuan, dimana mereka adalah seorang praktisi kesehatan atau seorang pendidik. Dengan dibantu seorang fasilitator atau helper tersebut seseorang dapat melihat buku bacaan dapat memberikan memberikan kita betapa luas khazanah pengalaman dan pengetahuan dimana pada akhirnya seseorang dapat mempelajari tantang segenap aspek kehidupan (Harvey, 2010)

Biblioterapi adalah jenis terapi yang unik yang menjadi perhatian dan banyak dikenal kalangan terapis beberapa waktu terakhir. Biblioterapi dengan menggunakan buku sebagai jalan untuk proses terapi yang bersipat kuratif bagi orang dewasa, pada penderita kecanduan minuman beralkohol. (Apodaca dan Miller, 2003) penderita depresi dapat digunakan membantu siswa yang berada dalam kondisi kritis dan mengalami penyakit kronik (Harvey, 2010). Untuk kepentingan preventif dan mayoritas digunakan dalam konteks pendidikan dan pembelajaran, baik pada anak-anak maupun orang dewasa. Dalam konteks ini, biblioterapi dipakai dalam pengembangan kemampuan tertentu misalnya kemampuan problem solving (Forgan, 2002), penumbuhan karakter dan merubah karakter (Parker, 2005; Marlowe dan Maycock, 2000), menumbuhkan self konsep dan perilaku belajar yang baik (Sridhar dan Vaughn, 2000), penumbuhan empati dan internalisasi nilai (Bouley dan Godfrey, 2008), supervisi konseling (Long, 2010), mencegah pemahaman dan perilaku yang berpotensi mendapatkan kekerasan seksual pada perempuan (Yeater, Naugle, O’Donohue, Bradley, 2004).

Penggunaan pada anak-anak dapat banyak membantu karena beberapa alasan, yaitu anak-anak mendapatkan pengetahuan tentang berbagai strategi pemecahan masalah hidup yang dialaminya dari pengalamannya menemukan berbagai karakter yang dibacanya dalam 
buku. Anak dapat mengidentifikasi karakter yang didapatkannya dari dalam buku dengan mudah, seperti kecemasan, depresi yang mereka sendiri mungkin merasakannya. Anak dapat menemukan berbagai alternatif yang dilakukannya untuk memecahkan masalahnya, dengan Biblioterapi anak dapat belajar memecahkan masalah yang mereka lihat dalam berbagai karakter yang ditemuinya dalam buku. (Harvey, 2010; Olsen 2007; Harper, 2010; Long, 2010; Forgan, 2002; Bouley dan Godfrey, 2008).

Buku bacaan adalah salah satu media yang biasa digunakan pendidik dalam proses pembelajaran. Dan dalam konteks inilah penggunaan bahan bacaan sebagai media menstimulasi penenaman kemampuan tertentu pada peserta didik mendapatkan relevansinya. Apalagi ditengah semakin memudarnya hoby membaca akibat tontonan dari TV dan media elektronik, seperti game yang mengandung unsur kekerasan yang lain, yang lebih dalam beberapa kecenderungan berimplikasi negatif pada diri seseorang (Manney, 2008). Pendidik dapat memilihkan bahan-bahan bacaan yang tepat dengan kondisi anak didiknya. Forgan (2002) menjelaskan beberapa jenis bahan bacaan yang dapat dipilih pendidik dapat bekerjasama dengan librarian, yang memiliki banyak pengetahuan dan data terkait buku-buku yang tersedia. Pemilihan bahan bacaan tergantung pada tujuan dan tingkat intervensi yang diinginkan.

\section{Tahap-tahap Biblioterapi dalam Konteks Pembelajaran}

Penggunaan biblioterapi dalam proses pembelajaran, terutama untuk penanaman karakter pada diri subyek belajar (peserta didik) dapat dilakukan dalam beberapa tahap. Proses penggunaan bahan bacaan diharapkan sebagai menjadi bentuk intervensi pada diri individu dalam aspek intelektual, emosional, dan perilakunya. Dengan mengadaptasi tahap-tahap biblioterapi, biblioteaching dapat dilaksanakan dalam tiga langkah utama, yaitu identifikasi, katarsis/involvement, dan insight (Marlowe and Maycock, 2000; Parker, 2010; Sridhar dan Vaughn, 2000) dan dapat diikuti follow up tertentu sebagai proses universalisasi (Olsen, 2007). Uraian di atas dapat digambarkan sebagai berikut: 


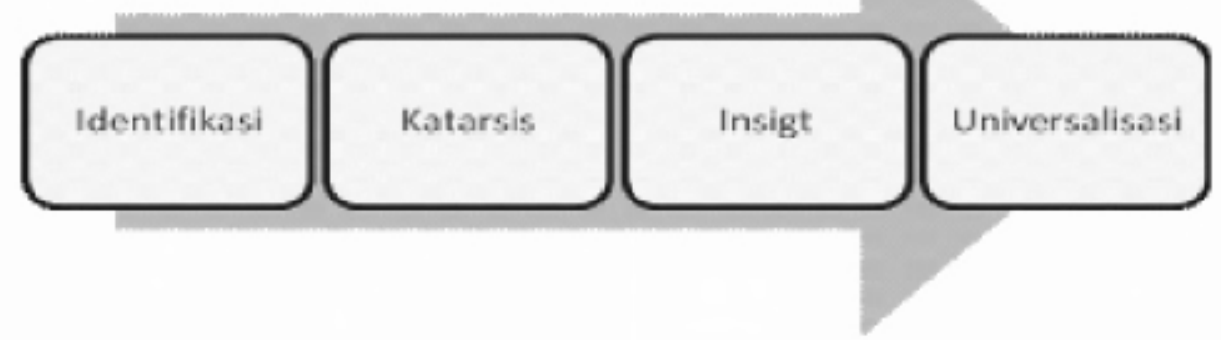

Penjelasan:

- Tahap Identifikasi

Anak akan mengidentifikasikan dirinya pada suatu karakter yang menyatakan kesamaannya dengan antara karakter dalam buku dengan dirinya. Mengkaitkan diri dengan salah satu karakter dibuku itu untuk memudahkan anak menyusun emosi dan memberinya pemahaman baru terhadap apa yang dipikirkannya.

- Tahap Katarsis

Katarsis adalah upaya melepaskan emosi. Pelepsan emosi anak ditunjukkan bahwa anak tidak sendiri dalam menghadapi masalahmya. Melalui katarsis anak dapat mengubah pola fikirnya dan belajar berdialog dengan pengalaman orang lain berdasarkan karakter yang dibacanya.

- Tahap Insight (wawasan yang mendalam)

Beda Biblioteaching dengan membaca biasa adalah siswa diberikan kesempatan untuk melakukan pengendapan, yaitu memindahkan emosinya dengan wawasannya yang mendalam atas situasi yang dihadapinya. Wawasan mendalam ini diungkap dalam suatu refleksi mendalam yang dilakukannya, kenyataan hidup didialogkan dengan situasi yang ada dalam buku.

- Tahap Follow Up

Setelah mengetahui bahwa dirinya tidak sendiri menghadapi masalahnya. Orang lain yang mengalami masalah juga bekerja keras dan berusaha menyelesaikan masalahnya. Tahap ini memberikan pembaca memiliki harapan, kesatuan dengan orang lain, dan situasi yang normal dalam dirinya (Parker, 2010; Sridhar dan Vaughn, 2000). 
Forgan (2002) membagi elemen penggunaan bahan bacaan dalam proses pembelajaran, yaitu prereading, guided reading, postreading discussion, dan reinforcement activity. Secara umum tahap-tahap pelaksanaan pembelajaran yang berpusat pada bahan bacaan dilakukan dengan empat aktivitas. Pertama, pre reading merupakan tahap pertama dimana pendidik memilih buku dengan bantuan librarian sesuai dengan kebutuhan. Dilanjutkan dengan pengenalan buku, baik cover dan isi, serta memainkan imajinasi peserta didik tentang isi buku. Kedua, peserta didik membaca buku dan pada banyak kesempatan guru memandu mereka untuk membaca dengan baik. Ketiga, peserta didik diajak menggunakan buku dan menghubungkan nya dengan kehidupan nyata, dan mendiskusikan buku dan menggambarkan kesimpulan isi buku. Keempat, menuntun mereka untuk mengambil pelajaran yang didapatkan dari buku, serta melakukan reinforcement dengan aktivitas follow up seperti menulis puisi, jurnal, debat terstruktur, role play, atau mempraktekkan pengalaman yang diperolehnya dengan orang kawan sebaya.

Tahap terakhir ini penting, karena penggunaan bahan bacaan akan efektif digunakan jika guru mempertajam penggunaannya dengan mengakhirinya dengan proses refleksi bersama, misalnya dengan memberikan pertanyaan dalam bentuk dilema-dilema untuk didiskusikan, atau anak mengekspresikan hasil refleksinya dalam bentuk tulisan dan karya seni misalnya gambar, karena tiap anak memiliki kemampuan berbeda untuk mengekspresikan emosi dan pikirannya (Sridhar dan Vaughn, 2000).

Hal ini akan dilakukan pada peserta didik dewasa yang akan menjadi calon guru. Dalam konteks ini penyiapan seorang pendidik atau seorang guru memiliki relevansi yang penting dalam suatu siklus dalam dunia pendidikan. Anak-anak dalam perkembangan dirinya guru mereka sebagai model moral (Cooper 2004). Mereka melakukan proses belajar dengan panutan mereka (model) dan kepada para guru mereka, hingga proses perkembangan fisik, emosional, dan pertumbuhan intelektual berlangsung dengan baik (Olsen, 2007). Selain karena bahan bacaan dapat digunakan untuk pendidikan preservice pada guru maupun pendidikan konselor (Long, 2010; Marlowe and Maycock, 2000). 


\section{Penumbuhan Empati dengan Menggunakan Biblioterapi}

Hasil penelusuran Marcy A Olsen (2006:11) menemukan berbagai penggunaan bahan bacaan digunakan oleh banyak guru dan para psikolog sekolah dalam banyak tujuan terapi maupun pembelajaran. Dalam konteks terapi dan konseling pada siswa Olsen (2006:11) menulis bahwa "bibliotherapy can help with an array of problems children face in school and life including anger, teasing, bullying, self-concept, abuse, aggression, anxiety, and death". Sementara pada konteks penggunaannya dalam proses pembelajaran menunjukkan bahan bacaan dengan dapat digunakan untuk membantu siswa meningkatkan "self-awareness and self-understanding and increase understanding and empathy for others". Fungsi lain yang dapat distimulasi dalam proses pembelajaran adalah fungsi preventif, dalam mencegah siswa terjerumus dalam situasi psikologis dan relasi sosial yang kurang sehat.

Jachna (2005:1) penggunaan bahan bacaan (literatur) dengan pendekatan terapi maupun pembelajaran adalah media yang utama dalam transfer pemikiran, menajamkan intelektualitas, dan dapat membangkitkan refleksi atas fenomena emosi --seperti kenikmatan, cinta, dan harapan -- yang terekam dalam kehidupan manusia. Empati adalah fenomena psikologis yang merentang dari rentang ruang kognisi - emosi manusia. Dan oleh karena itu penggunaan Biblioterapi dalam proses pembelajaran dapat digunakan untuk membangkitkan cinta dan empati pada diri seseorang. Hal yang penting bagi manusia, dan juga para remaja dan pemuda yang hidup dalam situasi sosial dimana kecenderungan agresi muncul akibat kompetisi tak terkendali, kekerasan, ketidak-pedulian antar sesama, suatu fenomena yang dapat menghancurkan masa depan manusia.

Salah satu tekhnik pembelajaran yang dapat menumbuhkan empati adalah dengan penggunaan kegiatan membaca bahan-bahan bacaan(Bouley and Godfrey, 2008:33-41), yang dalam berbagai tahapnya digabungkan dengan berbagai model pembelajaran atau tekhnik lain yang lazim dipakai dalam pembelajaran yang dapat menumbuhkan empati misalnya Role Playing (Douglas and Coburn, 2005), Story telling (Manney, 2008). Dan sesungguhnya role playing dan juga diskusi sendiri dapat digunakan sebagai follow up dalam suatu sesi pembelajaran yang berpusat pada bahan bacaan (Forgan, 2002). 


\section{Penutup}

Empati adalah suatu sikap simpatik yang didasari pemahaman yang mendalam, penuh kebersamaan, responsif, partisipatif, sensitif, dan mengenali pola pikir orang lain. Guru yang empatik telah menunjukkan suatu moral individual yang tinggi dimana dalam dirinya secara mental dan emosional dapat menghasilkan respon yang serupa dari siswanya. Dampaknya, mereka (guru) memberikan model serta membangkitkan moralitas mereka dalam relasi dengan murid maupun koleganya. Hal ini menunjukkan bahwa empati seorang guru memegang peranan penting dalam meningkatkan kualitas pembelajaran, membangun interaksi yang sehat dengan siswanya yang pada gilirannya membuat sutuasi belajar mengajar berlangsung sehat.

Metode biblioterapi dapat diadaptasi dalam situasi pembelajaran pada lembaga penyiapan tenaga kependidikan (guru), termasuk guru MI, yaitu untuk membangun kemampuan empati dalam diri seorang calon guru. Tahap-tahap yang biasa dilakukan adalah prereading (pra-membaca), guided reading (membaca dengan didampingi dosen), postreading discussion (diskusi setelah membaca), reinforcement activity (aktivitas penguatan).

\section{Daftar Pustaka}

Apodaca, Timothy R. and Miller, William R. 2003. A Meta-Analysis of the Effectiveness of Bibliotherapy for Alcohol Problems, Journal of Clinical Psychology, March 2003: 289-304.

Berenguer, Jaime. 2010. The Effect of Empathy in Environmental Moral Reasoning, Journal Environment and Behavior 42 (110).

Bouley, Theresa M. and Godfrey, Phoebe C. 2008. Reading Outside the Boundaries: Children's Literature as Pedagogy For Building Empathy and Understanding of Social Justice in the College Classroom, dalam The Journal of Effective Teaching Vol. 8, No. $1,33-41$.

Calwson. James G. 2006. "Role playing" dalam Clawson and Haskins, Teaching Management, Cambridge: Cambridge University Press. 
Carr, Mary B and Lutjemeier, John A. 2005.The Relation of Facial Effect Recognition and Emphaty to Delinquency in Younth Offenders, Journal of Adolesence, 40:159.

Cooper, Bridget. Empathy, Interaction and Caring: Teachers' Roles in a Constrained Environment, dalam Journal of Pastoral Care, Leeds, UK: Blackwell Publishing.

Decety, Jean dan Jackson, Philip L., 2006, A Social-Neuroscience Perspective on Emphaty, Journal of Current Directions in Psychological Science, Vol 15 (2).

Douglas, Kathy and Coburn, Clare. 2005, Students Designing Role-Plays: Building Empathy In Law Students? Journal Of The Australasian Law Teachers Association, 2005: 55.

Erich Andeman \& Linley Anderman. 2009. Psychology of Classroom Learning, New York: Macmillan Refference, part of Gale, Cengage Learning.

Floyd,Mark. 2003, Bibliotherapy as an Adjunct to Psychotherapy for Depression in Older Adults, Wiley Periodicals, Inc. Journal Clinical Psychology/In Session 59: 187-195.

Forgan, James W. 2002. Using Bibliotherapy To Teach Problem Solving, dalam Journal of Intervention In School And Clinic, Vol. 38, No. 2 (Pg. 75-82).

Gieser, Thorsten. 2008. Embodiment, emotion and empathy: A phenomenological approach to apprenticeship learning, London: SAGE Publications diakses dari situs http://ant.sagepub.com.

Haney, Kathleen. 2009, Emphaty and Otherness, Journal of Philosophy: A Cross-Diciplinary Inquiry Vol 4 (8).

Harvey, Pam. 2010 Bibliotherapy Use By Welfare Teams In Secondary Colleges, Australian Journal of Teacher Education, Vol 35/No 5, hal 29-39.

Hojat, MohamedRiza (2007), Emphaty in Patien Care, New York: Springer Science and Business Media. 
Hunter, John A. Figuerdo, Aurelio Jose., Becker, Judith V., Malamuth, Neil. 2007, Non Sexual Delinquency in Juvenile Sexual Offenders: The Mediating and Moderating Influences of emotional Emphaty, Journal of Family Violence, 22.

Jachna, T Joshua. 2005, Bibliotheraphy: What, Why and How, artikel pdf. di akses dari situs http://lilt.ilstu.edu/rlbroad/teaching/ studentpubs/oddisey.pdf.

Jamison, Christine and Scogin, Forrest. 1995. The Outcome of Cognitive Bibliotherapy With Depressed Adults, Journal of Consulting and Clinical Psychology, vol 63 no 4.

Kandemir, Mehmet., Özbay, Yaşar. 2009, Interactional Effect of Perceive Emphatic Classroom Atmosphere and Self-Esteem on Bullying, Elementary Educational Online, 8 (2).

Long, Richard P. 2010, Using Bibliotherapy as a Tools for Counseling Supervision, dalam Journal of Research in Innovative Teaching, La Jolla, CA USA: Publication of National University, Volume 3, Issue 1.

Manney, PJ. 2008. Empathy in the Time of Technology: How Storytelling is the Key to Empathy, Journal of Evolution and Technology - Vol. 19 Issue.

Marci A. Olsen, 2007. Bibliotherapy: School Psychologists' Report Of Use And Efficacy, Thesis of Educational Psichologist Bringham Young University, downloaded from: www.byu.ac.us/lib.

Marlowe, Mike and Maycock, George. 2000, "Phenomenology of bibliotherapy in modifying teacher puntitiveness," The Journal of Genetic Psychology, Vol 161(3).

Marlowe, Mike and Maycock, George. 2000, "Phenomenology of bibliotherapy in modifying teacher puntitiveness," The Journal of Genetic Psychology, Vol 161(3).

Marlowe, Mike and Maycock, George. 2000, "Phenomenology of bibliotherapy in modifying teacher puntitiveness," The Journal of Genetic Psychology, Vol 161(3). 
Marrs, Rick W. 1995, Meta-Analysis of Bibliotherapy Studies, American Journal of Community Psychology, Vol 23/No 6.

McKenna, Grainne and Hevey, David. Martin, Elaine. 2010. "Patients' and Providers' Perspectives on Bibliotherapy in Primary Care", dalam Jurnal Clinical Psychology and Psychotherapy Clin. Psychol. Psychother. 17, 497-509 Published online 8 February 2010 in Wiley Online Library (wileyonlinelibrary.com).

McMillen, Paula S. 2005.The Bibliotherapy Education Project:A Collaborative Teaching Effort Goes to the Web, Journal of Behavioral \& Social Sciences Librarian, Vol. 23(2).

Olsen, Marci A. 2007, Bibliotherapy: School Psychologists' Report Of Use And Efficacy (pdf), Universitas Young Bringham di download dari situs http://contentdm.lib.byu.edu/ETD/image/etd1274.pdf.

Parker, Karen L., "Reading for Character: Principles of Bibliotherapy Applied to Children's Literature." (2005). Faculty Publications and Presentations University of Liberty. Paper 2. Liberty University, DigitalCommons@Liberty University.

Rameson, Lian T. and Lieberman, Matthew D. 2009: Emphaty: Social Cognitive Neuroscience Approach, Journal Social and Personality Psychology Compass 3(1).

Slavin, Robert E. 2009, Psikologi Pendidikan: Teori dan Praktek (ed: terjemahan), Jakarta: PT Indeks.

Smith, Brian-Sutton. Mechling, Jay. et all (ed), 1995. Children's Folklore, Logon-Utah: Utah University Press.

Sridhar, Dheepa and Vaughn, Sharon. 2000, Bibliotherapy for All: Enhancing Reading Comprehension, Self-Concept, and Behavior, Journal of TEACHING Exceptional Children, Vol. 33, No. 2.

Stanbury, Stacey. Bruce, Mary. Jain, Alice Sachin. Stellern,John. 2010. The Effects of an Empathy Building Program on Bullying Behavior, Research Paper, University of Wyoming. 
Suparyo, Yossi. 2009. Artikel "Biblioterapi, Penyembuhan berbasis Ilmu Pengetahuan" diakses dari situs pribadi www.yossysuparyo. multiply.com/artikel_biblioterapi_html.

Tempel, Lorraine R. 2007, Pathway to the Clinicial's Experience of Emphaty in Engaging Sigle Mothers at Risk for Physical Abuse of their Childreen, Journal Clinical Social Work vol 35.

Trumpeter, Nevelyn N. Watson, PJ., O'leary, Brian J., Weathington, Bart L. 2008, Self Functioning and Perceive Parenting: Relation of Parental Emphaty and Love Inconsistency with Narcissism, Depression and Self Esteem, Journal of Genetic Psychology, 169 (1).

Weiner, Irving B., Reynolds, William M., Miller, Gloria E. (ed) 2009. Handbook Of Psychology (Volume 7) Educational New Jersey: John Wiley \& Sons, Inc.

Wing, Edgar H, Maret 2010, The Relationship between Therapist Emphaty, The Working Alliance, and Theraphy Outcames: A Test of a Partial Mediation Model, Disertasi Art and Sciences College, Ohio University.

Yeater, Elizabeth A. Naugle, Amy E., O'Donohue, William. Bradley, April R. 2004, Sexual Assault Prevention With College-Aged Women: A Bibliotherapy Approach, Jurnal Violence and Victims, Volume 19, Number . 
Sri Purnami 